\title{
O CONFLITO POSSESSÓRIO DA FAZENDA SANTA FILOMENA: UMA QUESTÃO DE PRINCÍPIO
}

\author{
Marina Basso Lacerda \\ Universidade Federal do Paraná. Graduação em Direito. $3^{\circ}$ ano. \\ e-mail: lacerdamarina@yahoo.com.br
}

\section{Orientadora: Vera Karam de Chueiri}

Professora adjunta de direito constitucional do departamento de direito público da faculdade de direito da UFPR. Mestre em direito pela UFSC e doutora em filosofia pela New School for Social Research, NY.vkchueiri@aol.com

RESUMO: A fazenda Santa Filomena é latifúndio improdutivo ocupado por integrantes do MST. O conflito possessório comportou decisões antagônicas, com viés político e constitucional. Trata-se de conflito de direitos fundamentais, que têm seu conteúdo definido no caso concreto, mediante a ponderação. Através deste método verifica-se que é adequada a manutenção das famílias na área, pela prevalência da dignidade da pessoa humana em relação ao direito de propriedade. Este direito, através da evolução do conceito, impulsionado através das lutas populares, hoje é limitado pela função social da propriedade, que, como princípio constitucional, é vinculante e estabelece um porder-dever ao proprietário. Como a Constituição é produto de forças políticas contrapostas, há nela armadilhas para a manutenção da estrutura fundiária existente. Porém, considerando-se o todo constitucional, essas interpretações devem ser excluídas quando da aplicação da norma. As escolhas políticas dos magistrados perante o conflito são legítimas na medida em que sejam decisões baseadas em princípios, que fazem a ponte entre moral e direito, assegurando diretos individuais ou coletivos. Assim, os movimentos sociais fazem do judiciário uma esfera de luta, buscando tais decisões, de modo a formar uma rede coerente de precedentes baseados na prevalência dos direitos fundamentais.

PALAVRAS-CHAVE: Conflito possessório. Movimento dos Trabalhadores Rurais Sem Terra. Ponderação. Princípios constitucionais. Direitos fundamentais. Propriedade. Função social. Decisões políticas. Coerência. 


\section{APRESENTAÇÃO DO CONFLITO POSSESSÓRIO}

A Fazenda Santa Filomena é um latifúndio improdutivo ${ }^{1}$. Por esta razão, foi ocupada, em 31 de julho de 2004, por cerca de 400 famílias integrantes do Movimento dos Trabalhadores Rurais Sem Terra - MST. A propriedade é situada no município de Guaraiçá, na região de Terra Rica, no norte do Paraná, a qual é extremamente belicosa no que diz respeito a conflitos agrários.

Os jagunços contratados pelos proprietários da área, em uma tentativa de despejo, atiraram contra as famílias sem terra, o que ocasionou, além de ferimentos sérios em sete trabalhadores, o assassinato de Elias de Meura, de 20 anos de idade.

Então, por ocasião da ocupação, os donos da fazenda impetraram ação de reintegração de posse em face dos sem terra. ${ }^{2} \mathrm{O}$ juiz federal substituto da comarca de Paranavaí - Matheus Gaspar - em novembro de 2004 concedeu liminar de reintegração de posse, desfavorecendo as famílias acampadas.

Esta decisão foi objeto de recurso perante o Tribunal Regional Federal da Quarta Região. O desembargador Edgard Lipmann Junior (também já citado), em um primeiro momento, cancelou esta liminar, reconhecendo que o perigo de dano eminente ameaçava os acampados. Porém, em seguida, deu novo despacho, cancelando a sua decisão anterior, por questões puramente processuais.

Inusitadamente, em 24 de janeiro de 2005, o mesmo juiz da comarca de Paranavaí cancelou decisão outrora por ele proferida, reconhecendo, desta vez, os

\footnotetext{
${ }^{1}$ Conforme Decreto de 17 de agosto de 1998, que declara a área como de interesse social para fins de Reforma Agrária.

2 No mesmo dia da interposição da ação de reintegração de posse, o juiz estadual da comarca de Terra Rica determinou a expedição de mandado de reintegração de posse, inclusive com deferimento de reforço policial. Ocorre que, por ser a competência para o caso da Justiça Federal, pelo fato de o INCRA ter interesse no caso, os autos foram retirados do juízo estadual, cancelando a liminar concedida.
}

Antes da tomada de posse da área pelo movimento, já existiam, em relação à fazenda, alguns processos jurídicos. Um deles, proposto pelo INCRA, objetivava a desapropriação por interesse social para fins de reforma agrária. E outras duas impetradas pelos proprietários: uma cautelar, que pedia a suspensão da classificação do imóvel como improdutivo, e outra ação declaratória de produtividade. Ambas, em primeiro grau - na Justiça Federal de Paranavaí, julgadas pelo juiz Matheus Gaspar - tiveram sentenças desfavoráveis aos proprietários, que não conseguiram comprovar a produtividade. Porém, em sede de recurso, a ação declaratória de produtividade acabou por suspender a ação de desapropriação mencionada - decisão esta proferida pelo desembargador Edgard Lipmann Junior. 
direitos das famílias acampadas. ${ }^{3}$ Por outro lado, surpreendentemente, o Des. Lipmann, em sede recursiva, dias depois, desta vez entendeu, antagonicamente a sua posição inicial, que ameaçados estavam os proprietários, fazendo valer, novamente, a medida liminar que concede a reintegração de posse da fazenda.

As decisões são eminentemente políticas e constitucionais. ${ }^{4}$ De acordo com a próprio juiz federal, em seu despacho, "No caso em tela, pode-se vislumbrar um conflito de interesses tutelados constitucionalmente: o direito a propriedade, sua função social, o devido processo legal, o direito à vida e à moradia."

\section{TEORIA DOS PRINCÍPIOS}

Os direitos fundamentais, na sua interpretação como princípios, não devem ser confundidos com enunciados programáticos. ${ }^{5}$ Pela característica de direitos subjetivos que são, são vinculantes, necessariamente exigíveis frente a um tribunal ${ }^{6}$. Assim, o entendimento da "função social da propriedade como mera recomendação do legislador e não como vinculação jurídica efetiva, tanto do Estado, quanto dos particulares é de ser expressamente repelida dos sistemas constitucionais que a exemplo do alemão e do brasileiro afirmam o princípio da vigência imediata dos direitos humanos." Além disso, os demais direitos relativos a sem terras em situação de ocupação, como à vida, à moradia, à saúde e o trabalho, todos positivados na Constituição brasileira, não podem de maneira alguma, serem colocados em segundo plano quando dos conflitos jurídicos.

\footnotetext{
${ }^{3}$ Hoje esta decisão encontra-se suspensa por força de Agravo de Instrumento, no qual o Des. Lipmann conferiu validade à primeira liminar, que concede a reintegração de posse, numa posição contraditória em face ao conflito, uma vez que agora alega que o pericumun in mora e o fummus boni iuris favorecem os proprietários.

${ }^{4}$ Nos parece conveniente, para tanto, as teorizações do jurista alemão BOROWSKI, cujo mestre é ALEXY, o qual traz importantes contribuições, através das categorias teóricas apresentadas.

${ }^{5}$ BOROWSI, M. La estructura de los derechos fundmentales.p. 61-62.

${ }^{6}$ BOROWSI, M. Idem p. 46

Neste sentido, importante a observação de Alexy: num sistema de tripartição de poderes, são juridicamente vinculantes aquelas normas de direitos fundamentais que são justiciáveis, ou seja, cuja violação possa ser averiguada por um tribunal. De acordo com 0 art. $5^{\circ}$ da Constituição brasileira, todos os direitos fundamentais são diretamente aplicáveis, o eu implica, também, em todos eles serem vinculantes. Mas, independentemente desta positivação, a justiciabilidade dos direitos fundamentais deve ser exigida, pois estes são essencialmente direitos do homem transformados em direito positivo, que exigem institucionalização. (ALEXY, Robert. Colisão de diretos fundamentais e realização de direitos fundamentais no Estado de Direito Democrático. Palestra proferida na Escola Superior de Magistratura Federal em 07 de dezembro de 1998.)
}

${ }^{7}$ COMPARATO, F. Direitos e deveres fundamentais em matéria de propriedade. p.141-142 
A função social da propriedade não confere meros limites negativos ao direito. Vai mais além: estabelece um poder-dever ao proprietário, estabelecendo deveres a serem cumpridos. Afinal, o adjetivo "social" implica na idéia de interesse coletivo. $^{8}$

Importa não esquecer que todo direito subjetivo se insere numa relação entre sujeito ativo e sujeito passivo. Quem fala pois em direitos fundamentais está implicitamente reconhecendo a existência de deveres fundamentais. Portanto, se a aplicação das normas constitucionais sobre direitos humanos independe da mediação do legislador, o mesmo se deve fazer em relação dos deveres fundamentais. ${ }^{9}$

Quando a Constituição diz que os direitos fundamentais têm aplicação imediata, reconhece que a exigibilidade dos deveres fundamentais também o é, independendo de regulamentação posterior. Aliás, o respeito aos deveres fundamentais ligados à propriedade privada não são relativos apenas ao particular, mas também devem ser objetos de política pública obrigatória, por força da Constituição, cuja não realização representa uma inconstitucionalidade por omissão. ${ }^{10}$

As normas de direito fundamental são normas de princípio. ${ }^{11} \mathrm{O}$ característico dos direitos fundamentais é a diferença entre o âmbito de proteção e o âmbito de garantia efetiva. São necessariamente restringíveis. ${ }^{12}$ Seu conteúdo é definido em confronto com demais princípios, no caso concreto, mediante ponderação. ${ }^{13}$

Princípios são normas que dizem que algo deve ser realizado tanto quanto possível de acordo com as possibilidades jurídicas e fáticas. São, portanto, mandamentos de otimização. ${ }^{14}$ Assim, quando o aplicador do direito se vê diante de

${ }^{8}$ COMPARATO, F. Idem, ibidem.

${ }^{9}$ COMPARATO, F. Idem. p. 141

${ }^{10}$ COMPARATO, F. Idem. p. 144

${ }^{11}$ BOROWSI, M. Idem p. 47

${ }^{12}$ BOROWSI, M. Idem p. 75

${ }^{13}$ BOROWSI, M. Idem p. 101

${ }^{14}$ ALEXY, Robert. Colisão de diretos fundamentais e realização de direitos fundamentais no Estado de Direito Democrático. Palestra proferida na Escola Superior de Magistratura Federal em 07 de dezembro de 1998. 
um conflito de direitos fundamentais, deve estabelecer uma determinação normativa mediante a ponderação de princípios. ${ }^{15}$

E é esta linha de raciocínio que o juiz Mates Gaspar, em sua segunda decisão, seguiu: "Assim, em que pese a proteção constitucional, o direito à propriedade não é absoluto e ilimitado, pois deve ser apreciado em harmonia com os demais direitos ou garantias constitucionais."

Quem entende os direitos fundamentais, em sua qualidade de princípios, como um chamamento a ponderar intuitivamente, como pretensão contida em um direito, interpreta totalmente mal a teoria dos direitos como princípios. Por ela o juridicamente devido deve ser resultado de um procedimento metódico. ${ }^{16}$

Não há um parâmetro vinculante para se proceder a ponderação. Mas a restrição somente é legítima, na medida em que atende ao princípio da proporcionalidade. ${ }^{17}$ Este princípio deve ser aplicado conforme os seus três subprincípios: o da idoneidade, o da necessidade e o da proporcionalidade em sentido estrito. ${ }^{18}$

Segundo o princípio da idoneidade, a medida adotada deve ser adequada para a obtenção de um fim legítimo perseguido pelo Estado. Os fins ilegítimos são aqueles cuja obtenção está proibida pela Constituição. A seguir deve ser observada a necessidade, mediante o qual a medida tomada será válida se não houver outra medida igualmente eficaz que atinja menos o direito fundamental afetado. Por fim, deve ser observado o subprincípio da proporcionalidade em sentido estrito, pelo qual a intensidade da intervenção deve ter peso proporcional ao das razões que a justificam. ${ }^{19}$ Aqui é que se dá a ponderação no sentido próprio. ${ }^{20}$

Através desse procedimento metódico, percebemos que acertou o juiz federal em sua decisão. A medida tomada, de não conceder a posse liminarmente, é adequada para assegurar às famílias os direitos fundamentais mencionados, sobretudo o devido processo legal (já que o deferimento de uma liminar de

\footnotetext{
${ }^{15}$ BOROWSI, M. Idem p.56

${ }^{16}$ BOROWSI, M. Idem p. 55

17 BOROWSI, M. Idem p. 77

${ }^{18}$ BOROWSI, M. Idem p. 57

${ }^{19}$ Borowski p. 130-131
} 
reintegração de posse não aguarda o desfecho do processo para determinar a expulsão das famílias da área). Ademais, como as famílias não tem outro local onde se possam fixar de maneira minimamente digna, não há outra medida que seja menos gravosa - se é que se pode considerar o acampamento gravoso, já que tratava-se da latifúndio absolutamente improdutivo, sendo que a ocupação, portanto, não causa prejuízos aos proprietários. De forma que se verifica também a proporcionalidade estrita da manutenção do acampamento, salientando-se que a fazenda já está em vias de ser desapropriada.

Ademais, o direito de propriedade que ganhou novos contornos no novo contexto constitucional. Assim, além de poder sofrer intervenção, implicitamente, devido às exigências sócio-econômicas concretas de reestruturação fundiária, a lei estabelece que este direito é suprimido quando não cumpre sua função social.

Vivemos uma contradição: a de que os direitos coletivos são possibilitados justamente na restrição dos direitos individuais de propriedade. ${ }^{21}$ Essa afirmação deixa de ser um paradoxo, porém, quando temos em conta a teoria dos princípios, pela qual os direitos fundamentais podem ser restringidos quando em colisão com outros, considerados mais importantes. A Constituição, ao colocar dentre os direitos fundamentais a função social da propriedade, submete o direito individual aos interesses coletivos. Assegura a propriedade como direito subjetivo, mas que não pode ser exercido de forma absoluta. ${ }^{22}$

Quando do sopesamento dos princípios, é de se ter em conta, sobretudo, a questão da possibilidade fática de concretização dos direitos fundamentais. Isso porque, de fato, a autonomia privada significa que os grupos com maior poder social podem oprimir os demais, tornando-se a igualdade perante a lei mero fator legitimador das desigualdades reais. ${ }^{23}$

Neste sentido, é importante termos em conta aqui o desenrolar da concepção acerca do direito de propriedade e as características que assume hoje.

\footnotetext{
${ }^{20}$ ALEXY, Robert. Colisão de diretos fundamentais e realização de direitos fundamentais no Estado de Direito Democrático.

${ }^{21}$ MARÉS, C. A função social da terra. p. 14-15

22 PEREIRA, R. A teoria da função social da propriedade rural e seus reflexos na acepção clássica de propriedade. p. 113-114

23 ALFONSIN, J. A terra como objeto de colisão entre o direito patrimonial e os direitos humanos fundamentais. p. 214
} 


\section{O DIREITO DE PROPRIEDADE E A FUNÇÃO SOCIAL DA TERRA}

A evolução jurídica da concepção de propriedade é diretamente vinculada às lutas sociais ${ }^{24}$ e as pressões, tanto por parte de oprimidos como por parte de opressores.

A concepção absoluta de propriedade se manteve fortemente durante quase todo o século $X X{ }^{25} \mathrm{O}$ primeiro passo, ainda que insuficiente, foi o reconhecimento da necessidade de produtividade à propriedade da terra. ${ }^{26}$

A Revolução Mexicana, embora traída, deixou marcas no sistema jurídico. A Constituição de 1917, com face marcadamente agrária, foi a primeira constituição social do mundo. Seu grande avanço é não ter sequer reconhecido como propriedade, áreas que não cumpriam os requisitos necessários de sua função social, e ter estabelecido a extensão máxima de terra que podia ser de um único proprietário. $^{27}$

É preciso aqui observar que a Constituição Mexicana e a de Weimar são quase contemporâneas, sendo aquela anterior a esta. A Constituição alemã estabelece que a propriedade obriga, que seu uso deve servir ao bem da coletividade. Esta constituição levou a função social da propriedade à categoria de princípio jurídico. ${ }^{28}$ Esta idéia "passou a acompanhar o Direito ocidental por todo o século XX, muitas vezes não entendida, outras não aplicada, omitida, deliberadamente esquecida, sempre presente nos discursos oficiais e distante das decisões judiciais." 29

A lei de Reforma Agrária da Bolívia também é paradigmática, pois inseriu no próprio conceito de propriedade da terra a função social, de forma que, na sua ausência, a terra deixava de ser propriedade. "Assim como a constituição mexicana,

\footnotetext{
${ }^{24}$ A este respeito ver MARÉS, C. A função social da terra.

${ }^{25}$ MARÉS, C. Idem. p. 88

${ }^{26}$ MARÉS, C. Idem. p. 14-15

27 MARÉS, C. Idem. p. 92-96

${ }^{28}$ FACHIN, L. A Função Social da Posse e a Propriedade Contemporânea. P. 17

${ }^{29}$ MARÉS, C. Idem. p. 86
} 
a lei boliviana reconceitua não apenas o exercício da propriedade, mas a legitimidade para ser proprietário."30

A bandeira da reforma agrária tanto na Bolívia como no México, unida à revolução, se mantém presente nos movimentos populares (...) a propriedade da terra, como direito, deveria sair do excludente protecionismo civilista e passar para a Constituição, cuja missão social é organizar o Estado e proteger o cidadão. (...) No final da década de 80` e início da de 90 muitos países latino-americanos reformulram suas constituições políticas, tentando um reencontro do Estado com o povo. ${ }^{31}$

O que fica claro nesse processo é que os direitos individuais não conseguem abranger os novos direitos, que são coletivos, aqueles pelos quais o povo se identifica como tal. Assim, o direito de propriedade já não pode assumir a mesma forma absoluta do século XIX.$^{32}$ É por isso que no caso da Constituição colombiana de 1991, os direitos coletivos públicos ou sociais se sobrepõem ao direito de propriedade. Esta constituição estabelece que a propriedade é uma função social.

Assim como nos outros países latino-americanos, sempre houve no Brasil uma política de excluir os pobres, camponeses e indígenas dum convívio em paz na terra. A luta pela terra sempre aconteceu, com ou sem projetos de reforma agrária. Ela é tão antiga quanto o latifúndio. Episódios como Canudos e Contestado, as batalhas camponesas brasileiras sempre foram omitidas, marcadas por extrema violência e dura criminalização dos líderes. ${ }^{33}$

No Brasil, a luta pela reforma agrária ganhou força principalmente a partir da década de 50, com o advento das ligas camponesas, participando não apenas os trabalhadores afetados, mas diversas instituições. ${ }^{34}$ Assim, a proposta de reforma agrária ultrapassava a visão ingênua do início do século, ganhando mais consistência, reivindicando não apenas a mudança do regime de posse da terra. Assim, as elites mudaram sua tática política: a repressão física passou a ser

\footnotetext{
${ }^{30}$ MARÉS, C. Idem. p. 98

${ }^{31}$ MARÉS, C. Idem. p. 100

32 MARÉS, C. Idem. p. 101

33 MARÉS, C. Idem. p. 106

${ }^{34}$ FERNANDES, B. O MST no contexto da formação camponesa no Brasil. p. 16
} 
acompanhada por propostas de mudanças jurídicas, "seguindo o lema mudar para que tudo continue igual". 35

Os projetos de desenvolvimento implementados durante a ditadura militar intensificaram a concentração da propriedade da terra e promoveram o maior êxodo rural da história do país. ${ }^{36}$ Enquanto a Constituição mexicana possibilitava o uso coletivo da terra e a boliviana mudava o próprio conceito de propriedade, o Brasil manteve íntegra a legitimidade contratual, através do Estatuto da Terra de $1964 .^{37}$

Em todas as Constituições brasileiras até a de 1988 o que está realmente protegido é o direito de propriedade, "porque a liberdade, a igualdade e a segurança são pressupostos da propriedade moderna e significam: contrato de homens livres e iguais, garantida sua execução pelo Estado."38 Mas a Constituição atual é um marco no sentido da consagração dos direitos sociais. E isso não é pouca coisa:

(...) as leis, embora não promovam mudanças na sociedade, as refletem. As mudanças que aparecem nas normas jurídicas são sinais da vontade social e solidificam os anseios da sociedade de rompimentos, melhoras e aperfeiçoamento. As novas leis podem ser o argumento para convencer os recalcitrantes sempre empoleirados no poder. ${ }^{39}$

\section{CONSTITUIÇÃO BRASILEIRA DE 1988}

"O absolutismo, no exercício da propriedade, sofreu a intervenção das idéias que progressivamente construíram a doutrina da denominada função social da propriedade." ${ }^{\prime 0} \mathrm{Em}$ face do teor da nova Constituição Federal, opera-se a

\footnotetext{
${ }^{35}$ MARÉS, C. Idem. p. 106

${ }^{36}$ FERNANDES, B. Idem. 24
}

${ }^{37}$ MARÉS, C. Idem. p. 108. O Estatuto da Terra permitiu um discurso reformista, humanizando os contratos, mas impediu uma quebra na tradição latifundiária. O essencial é que, apesar de delimitar a função social, não deixa claras as consequêencias dessa violação. Sua finalidade não era acabar com o latifúndio e alterar a estrutura agrária, mas garantir a produtividade da terra. (MARÉS, C. A função social da terra. p. 113.) O Estatuto da Terra resultou em letra morta, pela obvia falta de vontade política dos militares e porque o sistema jurídico continuava mantendo o direito de propriedade acima dos outros direitos. Além do mais, a necessidade de desapropriação, implicando num pagamento pelo não cumprimento da função social, está atrelado à velha concepção liberal de propriedade. O Estatuto da Terra foi um instrumento estratégico para desmobilizar as lutas sociais. (FERNANDES, B. O MST no contexto da formação camponesa no Brasil. 49)

\footnotetext{
${ }^{38}$ MARÉS, C. Idem. p. 34

${ }^{39}$ MARÉS, C. Idem. p. 14

${ }^{40}$ FACHIN, L. IdemP. 13
} 
constitucionalização deste direito no Brasil, o que tem forte significado diante da hierarquia interna do sistema jurídico. ${ }^{41}$

Assim, "nem toda propriedade privada há de ser considerada direito fundamental e como tal protegida”. ${ }^{42}$ Para fazer a distinção, a verificação deve-se dar em cada caso. É evidente que uma gleba urbana sub-utilizada, ou um latifúndio improdutivo, ou a propriedade de um bloco acionário, não podem ser considerados direito humano. ${ }^{43}$ "Quando a propriedade não se apresenta, concretamente, como uma garantia da liberdade humana, mas, bem ao contrário, serve de instrumento ao exercício de poder sobre outrem, seria rematado absurdo que se the reconhecesse o estatuto de direito humano, com todas as garantias inerentes a essa condição, notadamente a de uma indenização reforçada na hipótese de desapropriação."44

A propriedade que serve como poder de submissão não tem a natureza de direito humano, mas pode ser uma fonte de deveres fundamentais, ou seja, o lado passivo de direitos humanos alheios. "É, justamente, à luz dessa consideração da propriedade como fonte de deveres fundamentais, que se deve entender a determinação constitucional de que ela 'atenderá sua função social'."45

Cada vez que a Constituição garante a propriedade, determina que ela tenha uma função social. Afinal, para ser coerente com o compromisso de reduzir a desigualdade, a CF não poderia continuar com o modelo tradicional de propriedade privada. É tão insistente a Constituição que se pode dizer "que no Brasil pós 1988 a propriedade que não cumpre sua função social não está protegida, ou, simplesmente, propriedade não é."46

\footnotetext{
${ }^{41}$ FACHIN, L. A justiça dos conflitos no Brasil. p. 283

${ }^{42}$ COMPARATO, F. Idem. p. 139

${ }^{43}$ COMPARATO, F. Idem. p. 141

${ }^{44}$ COMPARATO, F. Idem. p. 140-141.

${ }^{45}$ COMPARATO, F. Idem. p. 141

${ }^{46}$ MARÉS, C. Idem. p.. 116
}

Neste sentido “(...) o Professor Guilhermino Benevides Melo inicia um brilhante ensaio dizendo que a desapropriação de terras na Colômbia somente é admitida quando cumprem sua função social, porque a desapropriação se faz de propriedades e aquela que não cumpre a função social propriedade não é. (...) a idéia da função social está ligada ao próprio conceito do direito. Quando a introdução da idéia no sistema jurídico não altera nem restringe o direito de propriedade (...) mantém a estrutura agrária integra" (MARÉS, C. A função social a terra. p. 91.) 
Apesar de a nossa Constituição estabelecer como inerente à propriedade em geral, a função social, este princípio "ganha substancialidade precisamente quando aplicado à propriedade dos bens de produção." ${ }^{47}$ A terra, bem de produção por excelência, atribui à função social de sua propriedade maior rigor, justificando inclusive intervenção do Estado para o adequado cumprimento dos requisitos para que desempenhe plenamente seu papel social. ${ }^{48}$

Não obstante o instituto da desapropriação estar previsto na Constituição, grande parte da doutrina tem priorizado o entendimento de que, como é a função social que legitima a propriedade, o seu não cumprimento implica em não ser protegida pelo direito, não havendo, portanto, motivos para indenização. Se o proprietário não cumpre os requisitos da função social, deixa de ter o direito de propriedade, não merece mais proteção pelo ordenamento jurídico. ${ }^{49}$

Na contramão da evolução doutrinária, a Constituição reconhece o direito de indenização mesmo a quem não cumpre sua função social e contraria a sistemática dos princípios constitucionais, o que evidencia o quão a Lei Maior é produto, nem

Essa posição provoca divergências. "A doutrina da função social da propriedade corresponde a um alteração conceitual do regime tradicional; não é, todavia, questão de essência, mas sim pertinente a uma parcela da propriedade que é sua utilização." A propriedade não é uma função social, mas tem uma função social. (Fachin, L.E. A função social da posse. P. 18 - 19) "A propriedade, assim, se justifica desde que cumpra sua função social; ela não é uma função social, mas tem uma função social, no que podemos definir função social da propriedade como os deveres positivos que devem ser exercidos pelo proprietário no exercício do direito de propriedade, ou seja, a observância de determinadas condições - o interesse coletivo - no exercício do direito de propriedade." (PEREIRA, R. A teoria... p. 100-101) A Constituição de 1988 não quis transformar a propriedade em função social, pois a estabeleceu no rol dos direitos individuais, em inciso próprio. Se fosse ela própria uma função social, ela não seria direito, mas ônus, dever. (PEREIRA, R. A teoria... p. 113)

47 PEREIRA, R. Idem. p. 110-111, citando Eros Roberto Grau, Elementos do direito econômico. São Paulo: RT, 1981, p. 128.

\footnotetext{
48 PEREIRA, R. Idem. p. 106

${ }^{49}$ ALFONSIN, J. Idem, p. 209
}

$\mathrm{Na}$ mentalidade de muitos juristas do século XXI que o direito de propriedade não pode ser desconstruído sem receber em troca outra propriedade, recompondo integralmente seu patrimônio individual. Aliás, "este radicalismo protecionista da propriedade privada imobiliária tem causado danos (...) na solução de problemas sociais graves (...)" (Marés. A função social da terra. p. 65) Os valores pagos nas desapropriações são invariavelmente maiores do que os do mercado, "sempre com a complacência do judiciário e a justificativa do formalismo jurídico." Através do instituto da desapropriação, recompondo o patrimônio até mesmo dos proprietários improdutivos, a "reforma agrária capitalista propunha apenas a mudança dos proprietários da terra, com uma dupla mobilização do capital: transformar terra improdutiva em produtiva e liberar dinheiro aos latifundiários para investir em outros negócios." (MARÉS. A função social da terra. p. 88) Só se pode desapropriar a propriedade. Se ela não existe, não há o que desapropriar. (GRAU, Eros Roberto. A ordem econômica na Constituição de 1988 - interpretação e crítica. São Paulo: RT, 1990. p. 316.) É antijurídico atribuir ao expropriado uma indenização completa. (COMPARATO, F. Direitos e deveres fundamentais em matéria de propriedade. p. 144) 
sempre coerente, de forças políticas da sociedade. Assim, paralelamente às conquistas dos movimentos sociais, "Quando a Constituição foi escrita, os chamados ruralistas, nome gentil dado aos latifundiários, foram construindo dificuldades no texto constitucional para que este não pudesse ser aplicado." 50

a grande derrota da luta pela reforma agrária aconteceu durante a elaboração da Constituição de 1988 (...). Embora a sociedade organizada tenha apresentado uma emenda popular com mais de um milhão e duzentas mil assinaturas, acabaram por prevalecer os interesses dos latifundiários. (...) Espertamente, a definição do conceito de propriedade produtiva ficou a cargo da legislação complementar. ${ }^{51}$

Foram também criadas armadilhas no próprio texto constitucional, para que estas leis inferiores seguissem determinado padrão de manutenção da estrutura fundiária estabelecida:

Pode-se perceber que as interpolações no texto constitucional foram intencionais. $\mathrm{O}$ artigo $185^{52}$ dispõe que o imóvel que seja produtivo é insuscetível de desapropriação, isto tem sido interpretado como: mesmo que não cumpra sua função social, a propriedade produtiva não pode ser desapropriada, o que inverte toda a lógica do sistema constitucional, porque se juntarmos esta interpretação com o equívoco anterior, a conclusão é desastrosa: a propriedade considerada produtiva não sofre qualquer sanção ou restrição pelo fato de não cumprir a função social. É verdade que apesar da habilidade dos autores, essas armadilhas não teriam êxito, e até seriam toscas, não estivesse coerente com a ideologia dominante, para a qual sempre é mais fácil qualquer interpretação que considere o Estado e seus poderes ao mesmo tempo guardiões e servos da propriedade. ${ }^{53}$

Esta interpretação inviabiliza o alcance dos princípios constitucionais, (vide art. $170^{54}$ ) e desconsidera toda a evolução da teoria da função social, e reduz o art. 186 à mera retórica. ${ }^{55}$

${ }^{50}$ MARÉS, Idem. p. 118

${ }^{51}$ FERNANDES, B. Idem. p. 43

52 "São insuscetíveis de desapropriação para fins de reforma agrária: outra;

I - a pequena e média propriedade rural, assim definida em lei, desde que seu proprietário não possua

II - a propriedade produtiva."

${ }^{53}$ MARÉS, Idem. p. 119

54 "A ordem econômica, fundada na valorização do trabalho humano e na livre iniciativa, tem por fim assegurar a todos existência digna, conforme os ditames da justiça social, observados os seguintes princípios: I - soberania nacional; II - propriedade privada; III - função social da propriedade (...)" 
A CF de 88 regride em relação ao Estatuto da Terra ao estabelecer que a propriedade produtiva é insuscetível de desapropriação para fins de reforma agrária. Talvez essa disposição tenha surgido justamente pelo avanço das forças sociais favoráveis a mudanças na estrutura agrária. Afinal, quando do Estatuto da Terra, não havia condições políticas minimamente indicativas da possibilidade de alteração no regime de propriedade da rural ${ }^{56}$, não sendo necessárias maiores prevenções legais, do ponto de vista dos latifundiários.

Retomando as teorizações de BOROWSKI, é importante termos em conta aqui um fenômeno semelhante ao da ponderação, mas aqui em relação a elaboração das leis infraconstitucionais. ${ }^{57}$ Trata-se da "configuração dos direitos fundamentais". Há duas formas de configuração. Uma delas é "desprovida de vinculação": o direito fundamental tem sempre o conteúdo que as leis lhe conferem, de forma que o legislador não é vinculado a um conteúdo prévio de direito. Essa compreensão, porém, não está de acordo com o sentido e a finalidade da vinculação do legislador aos direitos fundamentais. Desta forma, interessa a "configuração prevista de vinculação", mediante a qual o legislador está vinculado materialmente aos direitos fundamentais, vinculação esta que se deve dar por meio do princípio da proporcionalidade. ${ }^{58}$

Existe uma margem de ação, na qual o legislador é livre. ${ }^{59}$ Se assim não fosse, o processo político perderia seu significado. ${ }^{60}$ Mas essa ação legislativa está delimitada pelo conteúdo dos direitos fundamentais. As regras legais devem estar sustentadas por princípios constitucionais. A restrição de um direito fundamental proveniente unicamente da lei jamais poderá ser legítima. ${ }^{61}$

Justamente por estes motivos, é que é "claro que estas interpretações excludentes devem ser repudiadas de se atirar no lixo o texto constitucional. Mas as interpretações são equivocadas: tomam um inciso e omitem todo o conjunto da

\footnotetext{
55 MARÉS, Idem. p. 120

${ }^{56}$ MARÉS, Idem. p. 114

57 BOROWSI, M. Idem. p. 96

${ }^{58}$ BOROWSI, M. Idem. p. 87-90

59 BOROWSI, M. Idem. p. 60

60 BOROWSI, M. Idem. p. 169

${ }^{61}$ BOROWSI, M. Idem. p. 81
} 
obra."62 A Constituição precisa ser tomada como um todo. Com base no artigo 185 da CF vemos que propriedade produtiva o é desde que cumpra os outros requisitos da função social. ${ }^{63}$ De forma que, de acordo com FACHIN, a propriedade que merece proteção do ordenamento jurídico, na esteira do art. $184^{64}$, é aquela que atende todos os requisitos da função social simultaneamente. ${ }^{65}$

Cumpre observar que, no caso em tela, essas considerações seriam até mesmo irrelevantes, uma vez que se trata de propriedade improdutiva. Inquestionável, portanto, o não cumprimento da sua função social e o dever da União de desapropriação. Ainda assim, os representantes do poder judiciário tomaram decisões contrárias aos sem terra, o que denota, claramente, uma escolha política (assunto que abordaremos mais adiante).

\section{A POLÍTICA NA APLICAÇÃO DO DIREITO}

Da mesma forma que as forças sociais contrapostas são determinantes quando da elaboração das Constituição, esses elementos estão presentes na aplicação das normas ao caso concreto. Desta feita, embora a função social da propriedade "esteja clara por todo o texto constitucional, a leitura que tem feito a oligarquia omite o conjunto para reafirmar o antigo e ultrapassado conceito de propriedade privada absoluta." ${ }^{66}$ Há, ainda hoje, uma marcada ideologia na interpretação do discurso jurídico. ${ }^{67}$ É o caso do conflito possessório da Fazenda Santa Filomena, no qual, em um momento inicial em primeira instância, e ainda em esfera recursal, o todo constitucional é deliberadamente ignorado para favorecer os proprietários irresponsáveis.

Esta postura, que ainda é a da maioria do judiciário - embora os movimentos sociais estejam forçando interpretações que privilegiem a carga social da Constituição, como demonstrado com a segunda decisão do juiz federal, que

62 MARÉS, C. Idem. p. 121

${ }^{63}$ MARÉS, C. Idem. p. 121

64 "Compete à União desapropriar, para fins de reforma agrária, o imóvel rural que não esteja cumprindo sua função social (...)".

${ }^{65}$ FACHIN, L. A justiça dos conflitos no Brasil.

${ }^{66}$ MARÉS, C. Idem. p.116

${ }^{67}$ MARÉS, C. Idem. p. 13 
suspendeu a liminar anteriormente concedida - contribui decisivamente para o recrudescimento da violência no campo. "O crescimento dos conflitos agrários agravados pela concentração fundiária é diretamente proporcional ao compromisso com a inexecução da reforma agrária." 68

Exemplo disso é o conflito gerado quando da tentativa de desocupação da fazenda, que resultou inclusive em um assassinato de um trabalhador.

Conforme o relatório da CPI da violência no campo, seria injusto atribuir ao Poder Judiciário toda a responsabilidade pelas violências no campo. No entanto, parte de seus membros ter contribuído decisivamente com as injustiças, com a intocabilidade da propriedade privada, com a instituição do latifúndio e legitimando as formas mais absurdas de violência contra lavradores e apoiadores da reforma agrária. $^{69}$

A segunda decisão do juiz Matheus Gaspar demonstra que os clames dos movimentos sociais têm forçado avanços relativamente ao conservadorismo do poder judiciário. Aliás, o fato de ambos os magistrados - este e o desembargador federal - terem mudado de posição tão radicalmente, acerca do mesmo caso, em um curto espaço de tempo, demonstra o profundo e originário viés político de suas escolhas.

São importantes as reflexões de Dworkin sobre o assunto. ${ }^{70}$ Ele defende uma concepção do Estado de Direito centrada nos direitos. Portanto, nos princípios, segundo os quais os cidadãos têm direitos e deveres morais recíprocos e direitos políticos perante o Estado. ${ }^{71} \mathrm{O}$ juiz que adote este entendimento faz uma ponte entre a esfera moral e a jurídica das questões do caso, ${ }^{72}$ pois não se pode tratar, especialmente, controvérsias difíceis, somente com base em regras.

${ }^{68}$ FACHIN, L. Idem. p. 279

69 PEREIRA, R. Idem. p. 121. (relatório da comissão parlamentar de inquérito destinada a apurar as origens,causas e conseqüências da violência no campo brasileiro.Revista da Associação Brasileira de Reforma Agrária, n. 1, vol. 22/120. jan.-abr. 1992)

70 Princípios morais contrários podem ser ambos compatíveis com a legislação. Por isso dois juízes decidirão casos concretos de maneiras diferentes porque defendem visões diferentes. (DWORKIN, R. Uma questão de princípio. p. 16) Tradicionalmente se diz que os juízes não podem tomar decisões políticas porque eles não são eleitos. Deveriam aplicar a legislação tal qual ela se encontra. ${ }^{70}$ Mas, ora, aplicar a legislação de maneira neutra seria recorrer à intenção original dos legisladores. E encontrar essa vontade original exige argumentos que inevitavelmente são também políticos. (DWORKIN, R. Uma questão de princípio. p. 25,77)

71 DWORKIN, R. Uma questão de princípio. p. 6-7.

72 DWORKIN, R Idem. p. 15 
"Naturalmente, as decisões que os juízes tomam devem ser políticas", no sentido de que se devem basear em princípios nos quais acredita. ${ }^{73}$ Mas somente são legítimas as decisões políticas pautadas em argumentos de princípio que traduzem em algum direito individual ou de grupo $^{74}$

Ambos os magistrados - o juiz e o desembargador - tomaram decisões políticas antagônicas, em um curto espaço de tempo, frente ao conflito. Mas nem todas estas decisões são legítimas diante da teoria dos princípios. O desembargador passou de uma posição de garantir os direitos fundamentais dos sem terra, pautados na dignidade da pessoa humana, para, em seguida, entender que os mais ameaçados seriam os proprietários. O que se mostra absolutamente injustificável, já que, além das reflexões já apresentadas sobre o direito de propriedade, os donos, grandes latifundiários, não dependiam para a sobrevivência da fazenda, que era, além de tudo, improdutiva. Essa mudança de postura do desembargador não é abrigada pela teoria dos princípios, que depende de pressupostos morais. Seu posicionamento demonstra interesses políticos menores, que cedem às pressões dos latifundiários ao judiciário.

Por outro lado, é louvável o entendimento do juiz federal de primeira instância. Se, em um primeiro momento, cedendo ao tradicionalismo do poder judiciário, conferiu aos fazendeiros a reintegração de posse, em seguida, sensibilizando-se frente ao conflito, coerente com o todo constitucional, cancelou a liminar:

(...) O interesse individual, quando não atende a sua função social, resta superado pelo interesse coletivo(...) o caso não comporta uma decisão definitiva antes do julgamento dos recursos acerca da produtividade do imóvel, razão pela qual faz-se necessário analisar a conveniência da retirada de aproximadamente 250 famílias que ocupam o imóvel, em

${ }^{73}$ DWORKIN, R Idem. p. 3-4

O tribunal deve tomar decisões de princípio, e não de política, decisões sobre os direitos das pessoas e não sobre como alcançar o bem estar geral. (DWORKIN, R. Uma questão de princípio. 101). A respeito deste bem comum, "leia-se, mendigadas doses de bem-comum, (CHUEIRI, Vera Karam. Paradoxos. p. 160.) As decisões de política fazem um cálculo utilitarista, confrontando o dano para um litigante isolado com os ganhos que a sociedade em geral teria no caso de uma regra excludente. (DWORKIN. Uma questão de princípio. 113). "Qualquer legislação que possa ser justificada apenas pelo recurso às preferências da maioria sobre quais de seus concidadãos são dignos de interesse e respeito, ou que tipo de vida seus concidadãos devem levar, nega a igualdade." (DWORKIN, R. Uma questão de princípio. 99). Ou seja, as decisões não estão legitimadas pelo simples fato de contentar a maioria, já que isso poderia sufocar as minorias.

74 CHUEIRI, V. Paradoxos ..p. 159. Cirando DWORKIN, R. Taking rights seriously. P. 82. 
operação de risco evidente, demandando inúmeros recursos(...) ante a possibilidade de manutenção da sentença que julgou improcedente a declaratoria de produtividade.

A coerência do sistema normativo é uma exigência. Em toda decisão tomada pelo aplicador do direito se estabelecem novas determinações que podem ser desenvolvidas de maneira cada vez mais clara, até conformar um sistema de relações abstratas de precedentes. ${ }^{75}$ Através da defesa de uma concepção de Estado centrada nos direitos, o que se pretende é tecer uma rede de decisões que sejam pautadas nos princípios. ${ }^{76}$

É isso que está paulatinamente acontecendo com a jurisprudência recente relativa aos movimentos sociais, inserida em uma nova cultura constitucional, procurando considerar a integridade do ordenamento jurídico, posições estas que, cada vez são mais, difundidas dentre os magistrados, como é o típico caso da sentença que reconhece os direitos dos acampados em prioriedade relativamente aos dos proprietários.

Numa democracia o poder está nas mãos no povo. Mas nenhuma democracia oferece igualdade genuína de poder político. Assim, "como, normalmente, os ricos têm mais poder sobre o legislativo do que os pobres, pelo menos a longo prazo, transferir algumas decisões do legislativo pode, por esta razão, ser mais valioso para os pobres. Membros de minorias organizadas, teoricamente, têm mais a ganhar com a transferência, pois o viés majoritário do legislativo funciona mais severamente contra eles..."77 Aqui, obviamente, não se defende que todo o poder político seja transferido para os juízes, pois, se assim fosse, a democracia e a igualdade do poder político seriam destruídas. "Mas agora estamos considerando apenas uma classe pequena e especial de decisões políticas." $^{78}$

\footnotetext{
${ }^{75}$ BOROWSI, M. Idem. p. 58

76 "Assim, impera a moralidade pessoal do juiz - enquanto membro de uma instituição que comporta uma teoria política - através de sua argumentação baseada em princípios e a moralidade contida no precedente." (CHUEIRI, V. Paradoxos ... 1997. p. 160.)

77 DWORKIN, R. Idem. p. 31-32

78 DWORKIN, R. Idem. p. 30
} 
É desta forma que o MST - e outros movimentos sociais - tem feito do Judiciário uma esfera de luta, nas quais podem conseguir decisões favoráveis e avançar, assim, na construção de seu projeto de sociedade, centrado nos valores postos na Constituição, orientados pelo princípio da dignidade da pessoa humana.

\section{REFERÊNCIAS BIBLIOGÁFICAS}

ALEXY, Robert. Direitos fundamentais no Estado Constitucional Democrático: Para a relação entre direitos do homem, direitos fundamentais, democracia e jurisdição constitucional. Trad.: Luis Afonso Heck. In: Revista de Direito Administrativo. Rio de Janeiro, 217:55-56. jul./set 1999.

ALFONSIN, Jacques Távora.. A terra como objeto de colisão entre o direito patrimonial e os direitos humanos fundamentais. Estudo crítico de um acórdão paradigmático. In: STROZAKE, Juvelino José (org.). A Questão Agrária e a Justiça. São Paulo: RT, 2000.

BOROWSI, Martin. La estructura de los derechos fundmentales.Trad. Carlos Bernal Pulido. Bogotá, Universidad Externado de Colombia, 2003.

CHUEIRI, Vera Karam. Paradoxos da Auto-Observação: recursos da teoria jurídica contemporânea. Curitiba: JM Editora, 1997.

COMPARATO, Fábio Konder. Direitos e deveres fundamentais em matéria de propriedade. In: STROZAKE, Juvelino José (org.). A Questão Agrária e a Justiça. São Paulo: RT, 2000.

DWORIN, Ronald. O Império do Direito. Trad. Jefferson Luiz Camargo. São Paulo: Martins Fontes, 1999.

DWORIN, Ronald. Uma Questão de Princípio. Trad. Luís Carlos Borges. São Paulo: Martins Fontes, 2001.

DWORIN, Ronald. Levando os Direitos a Sério. Trad. Nelson Boeira. São Paulo: Martins Fontes, 2002.

ESPÍNDOLA, Ruy Samuel. Conceito de princípios constitucionais: Elementos teóricos para uma formulação dogmática constitucionalmente adequada. São Paulo, RT, 1999.

FACHIN, Luiz Edson. A Função Social da Posse e a Propriedade Contemporânea. Porto Alegre: Sergio Antonio Fabris Editor, 1988.

FACHIN, Luiz Edson. A justiça dos conflitos no Brasil. In: STROZAKE, Juvelino José (org.). A Questão Agrária e a Justiça. São Paulo: RT, 2000.

FACHIN, Luiz Edson. A justiça dos conflitos no Brasil. Revista da Associação Brasileira de Reforma Agrária - ABRA, n. 1, vol. 21/89, jan.-abr./1991. 
FERNANDES, Bernardo Mançano. O MST no contexto da formação camponesa no Brasil. In: STROZAKE, Juvelino José (org.). A Questão Agrária e a Justiça. São Paulo: RT, 2000.

MARÉS, Carlos Frederico. "A Função Social da Terra". Porto Alegre: Sergio Antonio Fabris Editor, 2003.

PEREIRA, Rosalinda P. C. Rodrigues. A teoria da função social da propriedade rural e seus reflexos na acepção clássica de propriedade. In: STROZAKE, Juvelino José (org.). A Questão Agrária e a Justiça. São Paulo: RT, 2000. 